\title{
Contact dermatitis due to methyl methacrylate: uncommon and unwanted entity for dentists
}

\author{
Paranjay Prajapati, Rajesh Sethuraman, Sucheta Bector, Jayanti R Patel
}

Department of Prosthodontics, KM Shah Dental College \& Hospital, Sumandeep Vidyapeeth, Vadodara, Gujarat, India

Correspondence to Professor Jayanti R Patel, drjpatel33@yahoo.com
To cite: Prajapati $P$, Sethuraman R, Bector $S$, et al. BMJ Case Rep Published online: [please include Day Month Year] doi:10.1136/bcr-2013200520

\section{DESCRIPTION}

Derivatives of methacrylic acid showing strong sensitising properties are frequent causes of allergic contact dermatitis in dentists and dental technicians. ${ }^{1-4}$

Methyl methacrylate is used for fabrication of acrylic removable partial or complete dentures for edentulous patients. Dentists, especially prosthodontists, are repeatedly exposure to these chemicals during various clinical and laboratory procedures. The most frequent sensitisers include 2-hydroxyethyl methacrylate, ethylene glycol dimethacrylate and methyl methacrylate.

Allergies to acrylates in dental professionals presents as itching and rashes of the contact areas. Images in this case report involve a postgraduate student in the Department of Prosthodontics of our hospital, who developed contact dermatitis due to exposure to methyl methacrylate monomer.

Initially small rashes which were pruritic in nature appeared on the dorsum of the hand (figure 1).

After $1 \mathrm{~h}$ of exposure, there was swelling of all fingers with small vesicles all over.

The next day the vesicles were ruptured and bleeding was observed from the ruptured sites (figure 2).

On the third day there was skin peeling off the swollen fingers. The extension of the finger was difficult and painful due to swelling (figure 3).

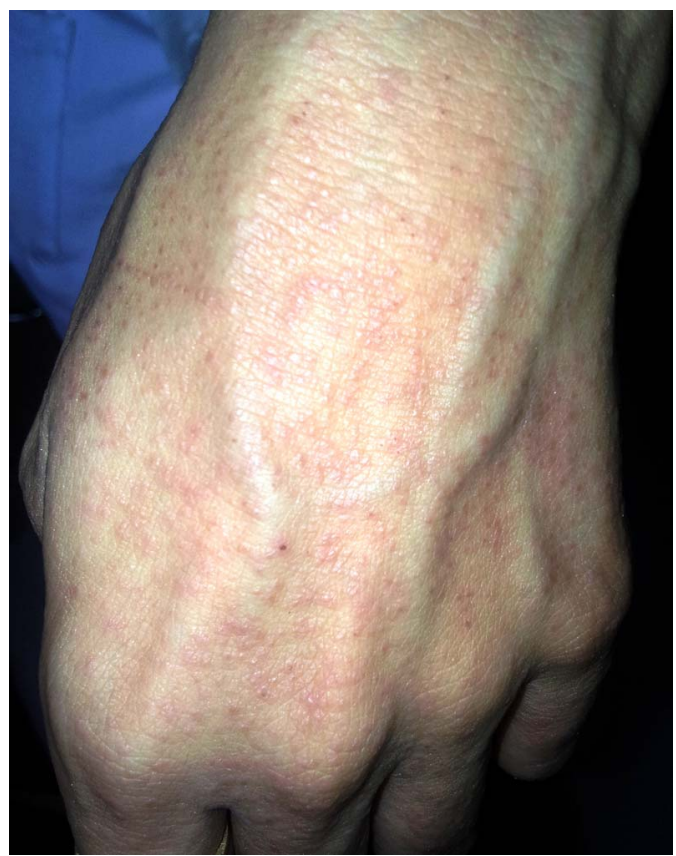

Figure 1 Immediately after exposure small rashes/ redness over the skin.

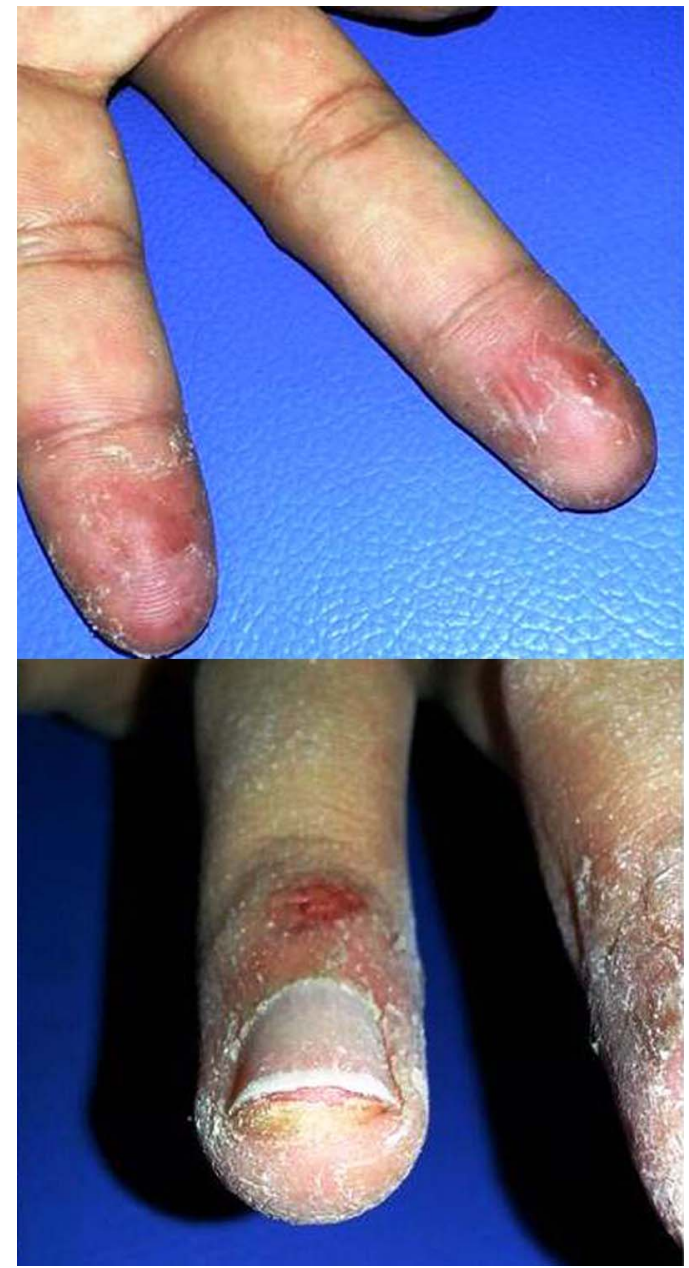

Figure 2 Oozing of blood from ruptured vesicles.

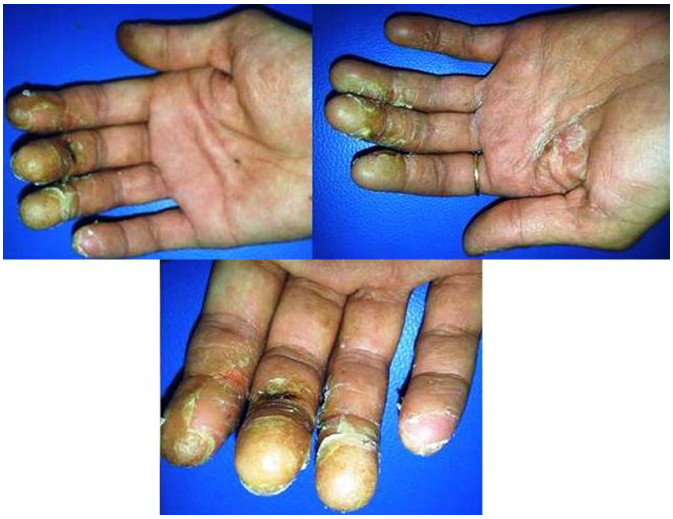

Figure 3 Peeling of skin and swollen fingers on third day after exposure. 


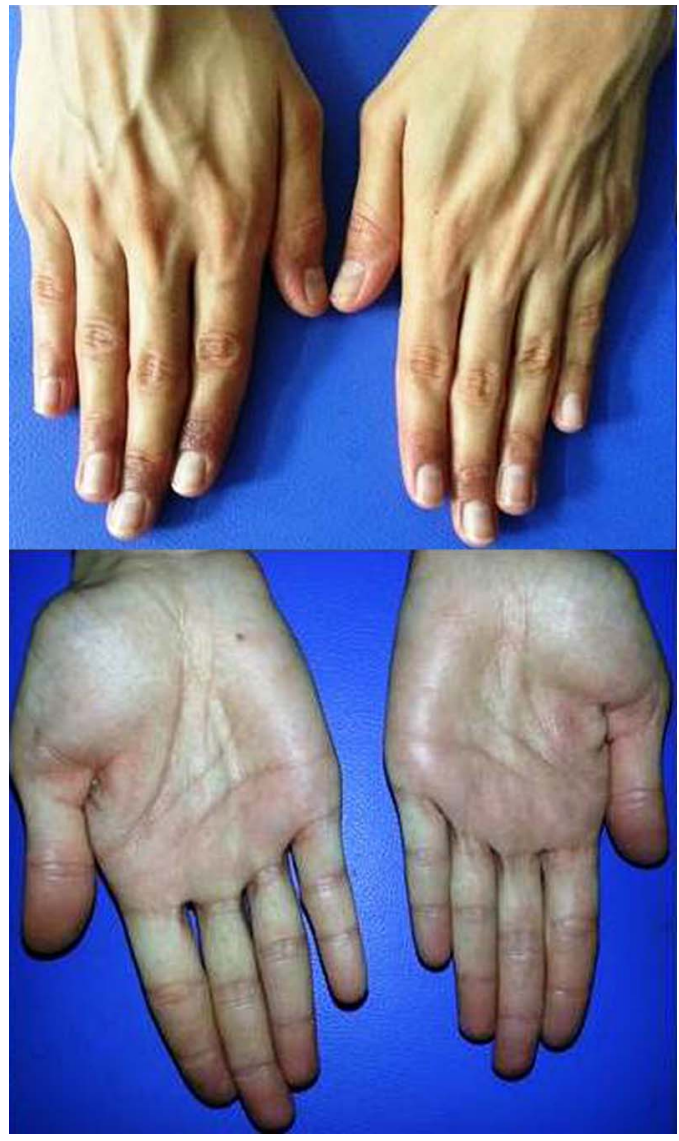

Figure 4 Hands after completely resolved condition.
After local application of steroid formulations and systemic antiallergic drug therapy condition was improved.

After 10 days of treatment the condition completely resolved back to normal (figure 4).

\section{Learning points}

- Contact dermatitis may be due to immediate or prolonged exposure to the foreign body.

- Dermatitis can be in form of rashes, itching, skin peeling or even bleeding and vesicles.

- People prone to such conditions should avoid direct contact with causative agents.

- Use of protective barrier is always indicated to avoid such incidence.

\section{Competing interests None.}

Patient consent Obtained.

Provenance and peer review Not commissioned; externally peer reviewed.

\section{REFERENCES}

1 Farli M, Gasperini M, Francalanci S, Gola M, et al. Occupational contact dermatitis in dental technicians. Contact Dermatitis 1990;22:282-7.

2 Kanerva L, Estlander T, Jolanki R, et al. Occupational allergic contact dermatitis caused by exposure to acrylates during work with dental prostheses. Contact Dermatitis 1993;28:268-75.

3 Kanerva L, Estlander T, Jolanki R. Occupational skin allergy in the dental profession. Dermatol Clin 1994;12:517-32.

4 Kanerva L, Jolanki R, Estlander T. 10 years of patch testing with the (meth) acrylate series. Contact Dermatitis 1997:37:255-58.

Copyright 2013 BMJ Publishing Group. All rights reserved. For permission to reuse any of this content visit http://group.bmj.com/group/rights-licensing/permissions.

BMJ Case Report Fellows may re-use this article for personal use and teaching without any further permission.

Become a Fellow of BMJ Case Reports today and you can:

- Submit as many cases as you like

- Enjoy fast sympathetic peer review and rapid publication of accepted articles

- Access all the published articles

- Re-use any of the published material for personal use and teaching without further permission

For information on Institutional Fellowships contact consortiasales@bmjgroup.com

Visit casereports.bmj.com for more articles like this and to become a Fellow 